\title{
Women and Seasonality: Coping with Crisis and Calamity
}

\author{
Janice Jiggins
}

\section{Introduction}

Over the last few years, a great deal of evidence has been amassed on the impact of seasonal adversities on women, children and their families. Attempts have been made to differentiate the varying impacts on households and, within households, on women and children in different income classes and to build dynamic models of the 'screws and ratchets' which push manageable seasonal stress toward the breakdown limits of livelihood systems.

What is attempted here is an exploration of the contribution of female production, labour and domestic domain services to the management of interannual and intra-annual uncertainty, the steps in the sequence of deterioration under accumulating stress, and of the options open to women and their children through and beyond the point of family disintegration, when managing seasonalities becomes a matter of individual physical survival.

The evidence of female mortality and morbidity rates, from some areas at particular times, suggests that the wastage of females may be countenanced in times of acute stress as necessary to the survival of social systems as a whole, however distressing at the level of family survival. It establishes the extreme end of a range of situations in which poor rural men and women act and react to expected inter-annual and intra-annual fluctuations, interspersed with shocks whose advent is always latent but whose timing and severity is unguessable.

The management of uncertainty is inherent in small producers' and labourers' livelihood systems; not surprisingly, these are characterised by flexibility, the maintenance of a range of options to meet expected fluctuations in resource endowments, entitlements to food, work and income, climatic variation and the unreliability of government services. If it is true that the less flexible the livelihood system, the harder it is to manage seasonal stress and sudden shock, then it is important to understand how and what different members of a household contribute to that flexibility.

Such an exploration leads to consideration of how members of households assess probabilities and how they express risk preferences. It has been fashionable, for example, to assert that small producers prefer to minimise risk by aiming for inter-annual yield stability around the minimum necessary to meet subsistence needs. The concentration on yield stability per se may be diverting attention from a more dynamic calculus in which household members complement each others' contributions to livelihood stability across seasons by maintaining the capacity to transfer resources in and out of the sub-systems which together constitute their livelihood.

In some enterprises, one family member might be happy to make a high risk-high pay off investment if assured that failure could be covered, or another to make a high input-low return investment if that return were deemed essential but could be gained in no other way. This calculus is likely to change over time. As in a commercial business, both risk preferences and probability assessments are likely to become more conservative after a run of bad years, as assets and room for manoeuvre dwindle and as investments made in the course of a run of good years have to be paid for out of shrinking revenues.

As households head into the bottom of the cycle, it becomes a fine run thing for many of them to maintain the flexibility to ride out the bad years. The need to concentrate time and effort on essential high inputlow return activities (such as fetching water from distant river beds in the dry season), may absorb household resources to the point of no return; households here must enter into new livelihood systems closer to the point of destitution, or disintegrate.

It is because men and women make separate if complementary contributions to the maintenance of

IDS Bullerin. 1986, vol 17 no 3. Institute of Development Studies, Sussex 
livelihood flexibility within the framework of expected inter-annual and intra-annual uncertainty, that not only the timing of a sudden shock but the gender of its victim(s) is important. The death of children from measles at the beginning of the agricultural season might provide greater room to manoeuvre to a couple seeking their daily living from an uncertain and gender-ascribed wage labour market or, on the other hand, remove essential labour at a critical moment from a female household head farming on her own account. The death of a husband for a relatively welloff woman in a tenant household might lead to her forced acceptance of the position of unpaid agricultural worker for her brother-in-law; the death of the wife, on the other hand, might offer her husband the opportunity for re-capitalisation of his farming activities through remarriage and the acquisition of a second dowry.

The options are various, the strategies complex and, it seems, as yet we understand very little about how these operate over time for households in different income groups or for individual household members. The following section explores briefly some of the ways in which women are contributing to the management of expected seasonal uncertainty and the maintenance of livelihood flexibility. Sections III and IV attempt a progression through time in the face of relentless seasonal adversity.

\section{Uncertainty and Flexibility}

Although neither the timing, distribution nor intensity of seasonal stresses may be known in advance, their advent and the range of probable fluctuation are accepted as normal occurrences by the rural poor. Among the range of possible responses, seven which tend to be particular to women are outlined here in brief.

\section{(i) Switching Tasks and Responsibilities ascribed by Gender}

In many rural societies, specific tasks and areas of responsibility are ascribed by gender. Where these are rigid, it might be that households - particularly low income households - find the management of seasonalities harder than in societies in which there is some scope for men and women to take over each other's tasks and responsibilities as need and opportunity arise. Contrast the following two examples. In an area of Tanzania in which only women cook and carry water, dry season watercarrying absorbs a great deal of female labour time. Men welcomed a proposed village water facility because, they said, 'Water is a big problem for women. We can sit here all day waiting for food because there is no women at home' [Wiley 1981:58].
In contrast, a Javanese case study reports greater scope for a more flexible response to gender-ascribed tasks and seasonal opportunities: 'Men, for example, sometimes stay at home to babysit and cook a meal while adult women and girls are off harvesting, or trading at the market' [White 1985:132].

In a study of the pastoral Orma along the Tana River in Kenya, Ensminger (1985) presents data which show only slight variation in the amount of time spent on or in the pattern of male and female activities between the seasons, except that, in the dry season, women do slightly less work such as cooking and milking and men spend more time in stock-watering and welldigging. Although young girls may take on some of the tasks associated with (male) herding, in general - at a time of maximum nutritional stress - men's dry season work increases somewhat whilst women's leisure time increases. Asking why there are 'relatively few age/sex cross-overs of labour allocation between seasons' (page 14), Ensminger finds that her data do not satisfactorily support explanations based on reproductive rationality, differential physiological efficiencies, social reproduction needs nor redistribution.

Indeed, it would seem that it is partly the social perception of the scope for switching rather than 'objective' assessments of capacity or returns which determines how flexible households can be in assigning seasonal labour tasks. In a study of labour market behaviour in South India, Ryan and Ghodake (1980) attempt to relate the effects of season, sex and socioeconomic status and speculate that differential labour market opportunities would support the economic rationality of skewed intra-household food distribution toward adult males but, as Schofield (1974) points out, we simply do not know if this presumed rationality leads to food being seasonally distributed independent of the task and sex of the operator: ' $\ldots$ are women fed more when weeding and men when ploughing? In this case, commonsense would suggest that available food is so distributed to the workers that the non-work force section bears the brunt of seasonal variation in food supplies' [Schofield 1974:26].

Where male and female farming are partially separated within the household livelihood system, the answer to the question of the intrahousehold pattern of income and food distribution in relation to women's labour productivity, as Jones (1982) has demonstrated for a Cameroonian case, may lie in calculations of the intrahousehold rate of compensation rather than market opportunity costs.

Another factor may be the degree to which ownaccount production is the main livelihood source. One 
study in Cajamarcan in the Andes found that in landless households depending on non-farming income-generating activities for the major part of their livelihood, a 'flexible sexual division of labour [in agriculture] appears to be required by economic necessity', whereas in landed households, agriculture is predominantly a male activity [Deere and de Leal 1982:88].

\section{(ii) Diversifying Household Income Sources}

It is common in development studies to see female income referred to as supplemental and for it to be subsumed within estimates of household income. Neither practice seems particularly helpful. For growing numbers of households headed by women, women's earnings form the main cash source; in households where male and female responsibilities are separated, women are obliged by the terms of their marriage contract to find the cash needed to fulfill their assigned responsibilities; amongst the poorest households, women's earnings may form an equal or larger share of household income; a greater portion of the income accruing to women than to men tends to be spent on household welfare and consumption needs. For all these reasons, in terms of seasonal analysis, the sex of the income-earner and the intra-household distribution of income and responsibility is thus likely to be more important than total household income as an indicator of the household's capacity to maintain itself in the face of seasonal adversity.

A number of studies do, in fact, show that women make careful judgements of the balance of advantage between, for example, maintaining food stocks and converting a portion to beer-brewing and selling as the agricultural season progresses [see Saul 1981 on sorghum beer-brewing in Upper Volta] or between allocating their labour to food production and processing for domestic consumption or to marketing [see Kebede 1978 for the balance between enset (the 'false banana') production and the chircharo system of trading among the Gurage in Ethiopia].

There is, further, growing evidence of the close correlation between female income-earning and childbearing: the higher women's income, the lower the number of pregnancies [Evenson 1985:27]. The causal relationship appears to be mediated through the monetisation of women's time. If we have evidence that changes in agriculture lead to an increase in women's time input with no increase in - or even loss of control over - their income, then we can expect that the adverse seasonalities associated with maternal and child health will, in fact, be exacerbated and may be contributing to the kinds of family breakdown outlined in Section IV.

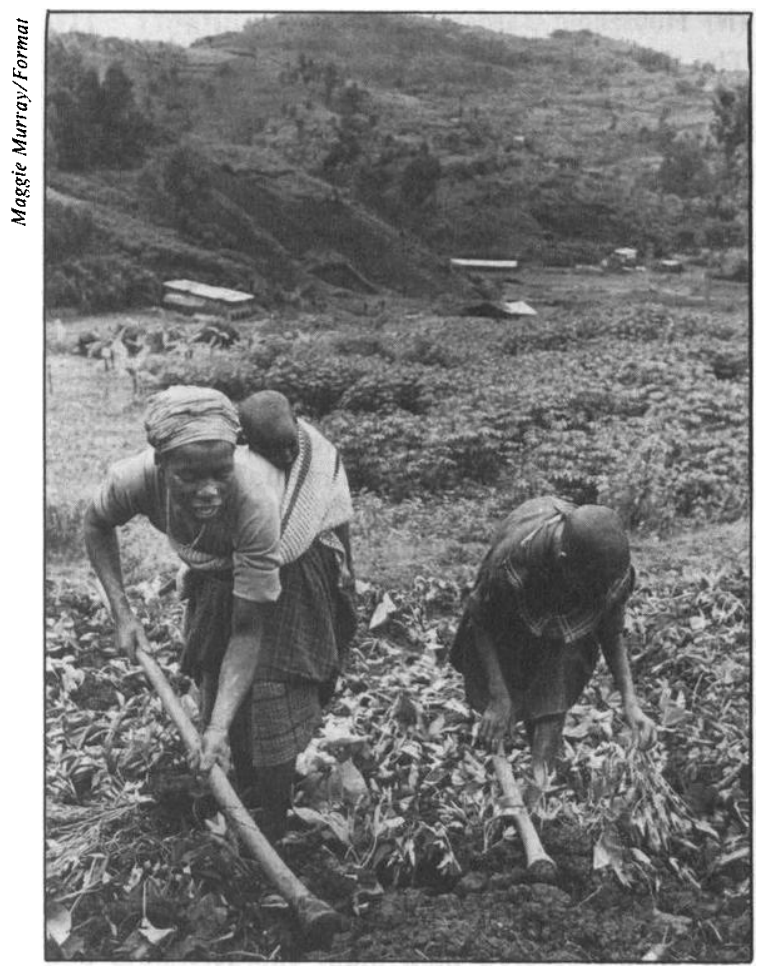

Women in Rwanda combining farming with child care.

\section{(iii) Changing the Intensity and Mix of Multiple Occupations}

There are good records of women manipulating the intensity of performance and the mix of occupations associated with their multiple roles in order to cope with seasonally urgent tasks. In general, it would appear to be their domestic domain roles which are squeezed rather than production or income-earning, though, as one would expect, the balance of net advantage may be different for women in households in different income classes [for a Philippines example see Illo 1985:85-7]. For example, surveys among primary school children in the Mochudi District of Botswana during the ploughing season showed that nearly one third of primary school children were caring for themselves without adult help in the month of February whilst parents were absent at the lands [Otaala 1980]. Cooking may be reduced to once a day or every two days during peak farm labour periods or staples substituted by snack foods which can be eaten raw [Bantje 1982a, Table 2; Jiggins 1986]. Ryan and Ghodake [1980] note for four South Indian villages that it is the hours women work in the domestic domain or as unpaid farm family labour which tend to fluctuate seasonally rather than the hours of waged work. 


\section{(iv) Household Gardening}

The domain of the household garden provides a further element of flexibility in the livelihoods of those with access to land. Studies from Grenada, Zimbabwe, West Africa, Jakarta, South East Asia and Peru emphasise the importance of household gardens under women's care as a source of early-maturing varieties of staples to carry families over the hungry season till main crops mature, as reserve sources of plant materials should main crops fail, as conservation sites for special or preferred varieties and as testing grounds for new varieties or practices [Brierley 1976; Callear 1982; Eijnatten 1971, Evers 1981, Ninez 1984, Stoler 1978]. A study in Kalimantan in Indonesia recorded an average of over 40 different species of vegetable, spice and fruit crops in household gardens [Watson 1985:198]. Local cultigens, semi-wild and protected wild species, together with small stock and poultry, may add to the diversity and richness, constituting a complex biological coping mechanism responsive to intra-annual and inter-annual climatic and labour time variations, meeting specific seasonal end-uses which cannot be provided by field crops, however abundant [Jiggins 1986].

\section{(v) Food Processing, Preservation and Preparation}

The choice of crop mix, plant characteristics and amount of time devoted to cultivation is not determined solely by consumption preferences nor are food purchases determined only by income; they are intimately associated with the technology available to women for domestic processing, preservation and preparation. These technologies in turn may be linked to the seasonal availability of different types of fuel for cooking and space heating [Foley et al 1984:34] and the differential fuels available to women in different income strata through the seasons [ibid 36]. Vidyarthi [1984] shows from data for one Indian village, the use of dung and firewood by women in bullock-owning households and an increasing reliance on crop residues by poorer women, who use spiky millet stems through the end of the Kharif season in November, then pigeon pea stems through the end of rabi in April (which give the best sustained heat of all residues), and then a weed, Ipomea fitulosa, which gives a smoky heat and must be gathered, cut and dried for a month before use, and gathered wood. He estimates that agricultural residues may form around 40 per cent of all fuels used by poorer women.

Huss-Ashmore details these links carefully for femaleheaded households in highland Lesotho [HussAshmore 1982:156]. In Mokhotlong the type of fuel used and the time spent getting it vary according to the seasonal availability of dung. Slow-cooking protein sources are not used equally through the year but are depleted during the cold season when the slow burning compacted dung is available. 'During the summer the population relies heavily on wild vegetable protein sources, which require more time to locate and gather but which can be rapidly cooked', using the horse and cattle dung picked up on the high pastures and kindled with quick-burning resinous and woody shrubs [ibid 157]. It is fuel seasonalities and not crop availability which determine which foods are eaten and the food preparation equipment used at different seasons.

Women also attempt to cope with crop seasonalities through food processing, to extend the storability and shelf life of perishables, from simple sun-drying of leaves and vegetables treated with soda ash, to more elaborate transformations such as those involved in the making of Kenke and gari (cassava products) in West Africa or chuno (potato products) in the High Andes.

\section{(vi) Social Organisation}

An apparently growing phenomenon is the formation of multi-generational, multi-locational networks of households headed by women. Only some of these are the result of family breakdown - women may be choosing to have children without what they perceive to be the burdens of marriage [Kerven 1979]. They appear to be an emergent form of social organisation designed to spread risk and optimise seasonal management strategies in areas of high gender-specific migration, marked seasonality, and marked genderspecific livelihood opportunities [see Kerven 1979 for Botswana examples; Phongpaichit 1980 for Thai examples].

Another strategy in areas where there is a developed labour market is for women from poor households to associate in specialist labour gangs to take advantage of seasonal cropping patterns. They may travel over a wide area, moving with the season from contract to contract, with gangs known for their speed and skill gaining premium rates. In a ten-member Sri Lankan gang documented in 1979, which moved from the wet zone to the irrigated dry zone twice a year to carry out paddy transplanting, six were married women, of whom two were separated from their husbands [ESCAP/FAO 1979:28-40]. The four resident husbands worked as casual labourers. The other women lived with their families, of whom only three had even a tiny plot of high land for cultivation. Their ages ranged from 26 to 55 years and they worked as casual estate labourers the rest of the year. Their transplanting earnings were spent on daily living and family needs; their own clothes and jewellery; furniture and pilgrimages. The high preference for turning their earnings into an easily convertible store of value under their own control, as a hedge against a crisis and calamity, has been noted in many studies [Jiggins 1983]. 
Yet another mechanism is to develop semi-formalised women's groups based on existing forms and principles of female association. Yet these might not be as useful as might at first be supposed in the maintenance of the poorer members' livelihoods through seasonal stress. In a study of women's groups in Kenya, members were asked to identify those who were 'famine resistant' or 'famine-prone' i.e. who would or would not be able to stand even a mild harvest failure or livestock disease. Famine-proneness turned out to be associated with illiteracy and household headship [Muzale and Leonard 1985:19]. Resurveyed after a year of drought, the membership was found to have dropped to those previously identified as 'famine-resistant'. The famine-prone had left the groups long before the groups suspended activities due to the drought and were not expected by those who were left to return.

'Participation in women's groups at the initial stages represents a form of long-term investment. At that stage, the groups do not yield material benefits for individual use in the family. Joint welfare funds, friendship, production information and skills are all the benefits that group participation is able to produce at the individual level at the initial stages. Women operating within small resource margins in a harsh environment are not likely to be able to undertake this form of investment on a continuing basis. If the groups' policies continue to demand contributions well into periods of environmental stress, poor women will be excluded' [Ibid:20].

Yet another mechanism - though possibly the reference is eccentric - is the practice of what might be termed 'seasonal polygamy': men contracting marriage with additional wives at the beginning of the crop season and divorcing them again afterwards, in order to optimise household labour resources when they are needed and to minimise the post-harvest draw down of household food stocks [Bantje 1982a:16].

\section{(vii) Gift-Giving}

Hidden within rural life is the special advantage that single, widowed and divorced and separated women may have to solicit and accept gifts from men in a relationship which falls short of prostitution in many respects but which women may skillfully exploit as a gender-specific coping strategy, even in societies in which propriety deems it a protective rather than exploitative relationship. Documentary evidence, unsurprisingly, is meagre. One example from Tanzania records a women's comment: 'We just look this way and that way for help. You see, I am a woman' [Bantje 1982b:7].

\section{Dealing with Relentless Adversity}

Given the kind of flexibilities described above, what gives way as families move into deepening poverty in the face of relentless adversity, such as several years of bad harvests? It seems we do not have sufficient information as yet to write about generalised patterns of how women adjust (nor of the effects of family adjustments on women) or to define precisely the parameters within which they occur. The following cases from the South Asian region, then, are only illustrative of the kinds of things which seem likely to happen.

A study of the sequential responses of deepening poverty in villages in two areas of Bangladesh, viz. Comilla and Modhupur, distinguished between female wage-earning households and those without female wage-earners and, within the former category, the position of widowed/divorced/separated women and married women [Begum 1985:221-41]. At some point in a run of bad harvest years, in smallholder households in which women did not work for wages, males sought or held non-agricultural wage jobs which at a pinch could compensate for loss of farm earnings. In smallholder households where women took wage work, men had no such alternative job and began to

'... lease out and perhaps sell land. They may also sell productive assets (e.g. bullocks) or consume productive inputs (e.g. seed). They may place male children in permanent jobs where they receive food and shelter. Finally, women may perform wage labour. The involvement of rural women in wage labour seems to be the last step in a series of family adjustments to economic crises that is taken only when the alternative is the effective breakdown of the family unit' [Ibid:232].

Households that had female wage earners also were more dependent on children's earnings. In particular, the higher percentage of labour participation of female children from female wage-earning households was found to reflect their acute poverty [Ibid:233-4].

There is an indication that the ability to support livelihoods through gleaning is dependent on the characteristics of the rice varieties grown. Among a number of differences between survey sites, the study pointed to the importance of the rice varieties grown as an index of the availability to women of harvesting wages, gleaning and post-harvest threshing employment.

'The long strawed broadcast aman rice grown in Comilla was less uniform in length. Consequently, some crops remained unharvested in the fields. On all land but that belonging to the poorest households, it was a prerogative of the women and children from poor landless households to glean 
the fields. They would then obtain access to a neighbour's dheki to dehusk the rice' [Ibid:235-6].

Women wage-earners from landless households were found to take almost a third of their earnings in the form of gleaning, begging and charity. There is some indication from a Sri Lankan study that petty thieving in cash or kind forms another kind of supplemental income for women in landless households under stress, particularly for those (not the poorest) who still have access to small scale consumption credit from traders or neighbours and who are pressed by their creditors to repay at times of seasonal stress [Risseeuw 1980:166].

The implication of the Bangladesh case, that whatever women's personal earnings or assets, these are consumed before the point of family breakdown, is also indicated by data from a case study of workers in the plantation sector of Sri Lanka. Women's earnings are 'eaten away by other people', their jewellery pawned or sold by their menfolk to cover debts and raise new credit, and their food intake reduced disproportionately as debt repayments cut into current income [Kurian 1981:134].

Another Bangladesh case illustrates how a woman from a poor household may be shuttled back and forth between her marital and natal home as seasonal crisis leads into greater poverty [Nath 1979]. Her parents are keen to marry her off, to relieve what is seen as a consumption burden but, similarly, suitors, poor themselves, are reluctant to take a wife without a dowry in compensation. Unable to pay the full dowry at one go, the bride is sent home whenever dowry payments fail - or the husband might demand more as his own problems worsen. The birth of a daughter or economic crisis in the natal or marital home then leaves the wife as an unwelcome presence in either household, neither accepting responsibility, until she finds herself abandoned by both.

Food aid disbursements and Food for Work (FFW) schemes of fer seasonal relief for some women who are approaching or who are beyond the point of family breakdown. Studies of the Employment Guarantee Scheme in Maharashtra, India [Institute of Social Studies 1979] and the Food for Work programme in Bangladesh [World Food Programme 1979, Rahman Khan 1979] record unexpectedly high proportions of women turning up for work. Nearly half of all the women surveyed in Bangladesh FFW schemes were found to be the main income earners for their families and of these, more than two thirds were widowed, separated or divorced [WFP 1979].

\section{Desperate Measures}

Crushed by poverty to the point where there is no flexibility left for surviving seasonal stresses or faced by sudden disaster, a man may decide to push his wife and children out of the house or to walk out on them. Greenough infers from the high percentage of adult women ( 56 per cent) applying for relief and the fact that a quarter of all adult applicants were living away from their spouses in a study of more than 3,000 relief recipients in Bengal during the 1943 famine, that the deliberate separation of spouses is a common response to crisis. He further quotes a survey of street-dwellers in Calcutta during the 1943 famine which similarly suggests that 'the exclusion of women from domestic subsistence' was the major direct cause of their arrival in Calcutta [Greenough n.d.:5; Greenough 1982]. The turning points in six of the case histories he presents are summarised in Table 1.

Beyond the point of family breakdown caused by deepening poverty and sudden shocks such as the death of a husband, or flood, there are a number of last desperate measures women may take - or be forced into taking - to save themselves and their children. Briefly, they might be listed as follows:

(i) migration, often involuntary, after they have been pushed out of the marital or natal house or the husband has abandoned the family [Scott 1984:50; Obbo 1980; Jahan 1979; Rahaman 1981]. A large number of involuntary women migrants turn to begging and vagrancy. Jahan [1979:270] remarks of the Bangladesh situation: 'The basic cause of [female] vagrancy is poverty, destitution brought on by the death/disability of male guardians or crop failure in densely populated areas.'

(ii) either just before or shortly after family breakdown, efforts might be made to place (especially male) children in others' households where they will work in return for food [Rahman Khan 1979] or they are left outside an orphanage, or they are bought and sold in return for food, or, in worst case situations, simply abandoned [Rahaman 1981:136].

(iii) changes in the character and intensity of gathering or cultivation of wild and semi-wild foodstuffs, preferred species giving way to famine foods which become a major or even the only food source [Rahaman 1981]. Anecdotal evidence from famine relief workers suggests that often it is women who preserve knowledge of the whereabouts and preparation of these foodstuffs.

(iv) failing all else, prostitution, for adult women and female children, may be the last resort. A study of 273 prostitutes in Dhaka [Jahan 1979:270-4] and the case material from Bengal adduced by Greenough (1982) suggest that it is impoverishment, made unsupportable by flood or famine, and the loss of male guardian or 
The Fate of Women during the 1943-44 Bengal Famine

\begin{tabular}{|c|c|c|c|c|c|c|c|}
\hline Cases & $\begin{array}{l}\text { Original } \\
\text { Household } \\
\text { Status }\end{array}$ & $\begin{array}{l}\text { Main } \\
\text { Livelihood }\end{array}$ & Crisis & Debt & $\begin{array}{l}\text { Distress } \\
\text { Sales }\end{array}$ & Dearhs & $\begin{array}{l}\text { Alternative } \\
\text { Livelihoods }\end{array}$ \\
\hline $\begin{array}{l}\text { A. } \\
\text { 1. Sankari } \\
\text { Addy } \\
\text { Hindu }\end{array}$ & $\begin{array}{l}1 \text { acre } \\
\text { smallholder } \\
\text { Recently } \\
\text { married } \\
\text { (18 year) }\end{array}$ & $\begin{array}{l}\text { Betel } \\
\text { vines }\end{array}$ & $\begin{array}{l}\text { Flood } \\
\text { Famine }\end{array}$ & & & & $\begin{array}{l}\text { Driven out to beg for food. Lived on gruel } \\
\text { at free kitchen for } 1 \text { month. Left to find } \\
\text { more food. Fainted on highway. Taken } \\
\text { into hospital. Husband remained on farm } \\
\text { to tend betel vines. }\end{array}$ \\
\hline $\begin{array}{l}\text { 2. Aifalijan } \\
\text { Moslem }\end{array}$ & & & $\begin{array}{l}\text { Crop } \\
\text { Failure } \\
\text { Famine }\end{array}$ & & $\begin{array}{l}\text { 1. Hut } \\
\text { 2. Utensils } \\
\text { 3. Labour } \\
\text { 4. Everything } \\
\text { but cloth- } \\
\text { ing. }\end{array}$ & $\begin{array}{l}\text { Mother died } \\
\text { when she } \\
\text { was young. } \\
\text { father soon } \\
\text { after her } \\
\text { own marriage. } \\
\text { Only son } \\
\text { died after } 10 \\
\text { weeks of } \\
\text { famine. }\end{array}$ & $\begin{array}{l}\text { Husband divorced her, then abandoned } \\
\text { her to join the army. Wandered from } \\
\text { free kitchen to free kitchen. }\end{array}$ \\
\hline 3. No name & $\begin{array}{l}\text { Farmer. Well- } \\
\text { off for first } \\
12 \text { years of } \\
\text { marriage }\end{array}$ & $\begin{array}{l}\text { Agriculture } \\
\text { 2-room hut, } \\
\text { cowshed. } \\
\text { kitchen, } \\
2 \text { bullocks. } \\
\text { Some agri- } \\
\text { cultural tools. }\end{array}$ & $\begin{array}{l}\text { Crop } \\
\text { Failure }\end{array}$ & $\begin{array}{l}\text { 100Rs } \\
\text { June, } \\
\text { July }\end{array}$ & $\begin{array}{l}\text { 1. Bullocks, } \\
\text { roof sheets, } \\
\text { windows } \\
\text { and doors; } \\
\text { day labour. } \\
\text { 2. utensils, } \\
\text { ornaments, } \\
\text { furniture. } \\
\text { 3. Mortgaged } \\
\text { last room. }\end{array}$ & $\begin{array}{l}10 \text { years old } \\
\text { eldest child } \\
\text { after weeks } \\
\text { eating only } \\
\text { boiled } \\
\text { vegetables. } \\
\text { Within } 3 \\
\text { days, } 2 \text { further } \\
\text { children. }\end{array}$ & $\begin{array}{l}\text { Husband unable to bear the calamity } \\
\text { and left. She was collected by her mother } \\
\text { and brought back to her father's village. }\end{array}$ \\
\hline
\end{tabular}

\begin{tabular}{|c|c|c|c|c|c|c|}
\hline $\begin{array}{l}\text { B. } \\
\text { 4. Sinhabala } \\
\text { Mandal } \\
\text { Hindu }\end{array}$ & $\begin{array}{l}1 / 3 \text { acre owned } \\
\text { by husband. } \\
\text { Household of } \\
\text { self, daughter, } \\
\text { husband, his } \\
\text { elder brother/ } \\
\text { wife/ } 6 \text { child- } \\
\text { ren; father-in- } \\
\text { law }\end{array}$ & $\begin{array}{l}\text { Day } \\
\text { labouring } \\
\text { Cow }\end{array}$ & Famine & $\begin{array}{l}\text { Brass and } \\
\text { bell-metal } \\
\text { utensils, } \\
\text { Cow }\end{array}$ & $\begin{array}{l}\text { Father-in-law } \\
\text { after eating } \\
\text { inedible food } \\
\text { Husband, of } \\
\text { malaria, after } \\
\text { returning } \\
\text { from search } \\
\text { for food. One } \\
\text { nephew. }\end{array}$ & $\begin{array}{l}\text { Ate wild vegetables. Father claimed her } \\
\text { but made her sell the } 1 / 3 \text { acre in return } \\
\text { for a room at his house. Some years later. } \\
\text { married off her daughter and was joined } \\
\text { by her son-in-law. }\end{array}$ \\
\hline \multicolumn{7}{|l|}{$\mathrm{C}$. } \\
\hline $\begin{array}{l}\text { 5. Puntibala } \\
\text { Sing }\end{array}$ & $\begin{array}{l}\text { Crippled } \\
\text { father, } \\
\text { mother, step- } \\
\text { mother, self, } \\
\text { husband }\end{array}$ & & Flood & $\begin{array}{l}\text { All } \\
\text { possessions }\end{array}$ & $\begin{array}{l}\text { Husband, } \\
\text { father, step- } \\
\text { mother, by } \\
\text { drowning. }\end{array}$ & $\begin{array}{l}\text { Protected by wealthy viliage man for } \\
4 \text { months. Returned to protection of } \\
\text { neighbour who was poor. Ate wild } \\
\text { foodstuffs. Left to seek food. Begged at } \\
\text { office of a landlord. Given food, shelter, } \\
\text { a room by the market. Violated. Began } \\
\text { life as prostitute under landlord's } \\
\text { protection. Eventually formed own } \\
\text { brothel. }\end{array}$ \\
\hline $\begin{array}{l}\text { 6. Angurbala } \\
\text { Sing }\end{array}$ & $\begin{array}{l}\text { Father a } \\
\text { share-cropper }\end{array}$ & Agriculture & $\begin{array}{l}\text { Cyclone. } \\
\text { Father's } \\
\text { house } \\
\text { destroyed. } \\
\text { Later } \\
\text { found } \\
\text { husband's } \\
\text { house } \\
\text { destroyed. }\end{array}$ & & $\begin{array}{l}\text { Mother and } \\
\text { sister, when } \\
\text { father's house } \\
\text { swept away. } \\
\text { Husband, } \\
\text { when own } \\
\text { house swept } \\
\text { away. }\end{array}$ & $\begin{array}{l}\text { Returned to father. Lived on charity/ } \\
\text { government relief. For } 4 \text { months under } \\
\text { protection of wealthy man. Fled before } \\
\text { raped. Contacted former female villager } \\
\text { (who was already a prostitute) for } \\
\text { assistance. Fell into operator's hands. } \\
\text { Father given agricultural work far away. } \\
\text { After } 5 \text { years, opened own brothel. }\end{array}$ \\
\hline
\end{tabular}

Notes: A. Wives deserted by or pushed out by husbands.

B. Better-off wife able to survive disaster.

C. Wives who lost everything and ended up in prostitution.

Source: Constructed from case notes presented in P. R. Greenough: 'Some notes on peasant prostitutes recruited in times of famine', Wid notes, Mucia Wid Network, Land Tenure Centre, University of Wisconsin, Madison, n.d., pp4-7. 
spouse (through death, divorce or desertion), which are the main causes leading women into involuntary prostitution.

\section{A Reconsideration of Seasonal Uncertainty and Calamity}

The largely descriptive information presented here perhaps allows us to make a preliminary sketch of the role women play in the maintenance of livelihood in the face of seasonal uncertainty and calamity, to begin to frame more discerning questions concerning risk preferences and probability assessments, and to look again at the valuation of women's labour time.

In Table 2, a very simple summary is attempted of the particularly female options open for the maintenance of livelihood in the face of seasonal crisis and calamity, for two categories of poor households, landed and landless. It is fairly heroic, ignoring all regional and continental differences in the social organisation of production and gender relations. Nonetheless, it suggests a number of patterns which might turn out to be general.
One feature which stands out is the resilience of female-headed household networks to seasonal stress and calamity; far from being among the 'most vulnerable', more critical study of the advantages of their organisational and economic flexibility may show that they are the 'survivors'. In this light, it may be that the prevalence of such networks in subSaharan Africa is a very rational and positive response to harsh and prolonged environmental crisis.

The Table also suggests that it might be possible to construct a matrix of male and female risk preferences and probability assessments, for households in different social classes and at various stages of decision-making, in the sequence from crisis to calamity

Finally, it suggests that a good deal more thought has to be given to the valuation of female labour time. Not only is it not constant along the domestic domain public domain continuum nor in relation to the value of male labour time, but it would seem on the face of it to fluctuate in relation to the importance of women's livelihood contribution through the sequence of crisis to calamity.

Table 2

Seasonal Crisis and Calamity: An illustration of female options

\begin{tabular}{|c|c|c|c|c|}
\hline \multirow[b]{2}{*}{$\begin{array}{l}\text { Extent to } \\
\text { which: }\end{array}$} & \multicolumn{2}{|c|}{ Seasonal Crisis } & \multicolumn{2}{|c|}{ Calamit! } \\
\hline & Landed & Landless & Landed & Landless \\
\hline $\begin{array}{l}\text { Male/female tasks and } \\
\text { responsibilities can be } \\
\text { switched }\end{array}$ & Only under real pressure & Yes & Yes & Yes \\
\hline $\begin{array}{l}\text { Domestic domain tasks } \\
\text { can be squeezed }\end{array}$ & Only under real pressure & Yes & $\begin{array}{l}\text { Yes. at the cost of family } \\
\text { welfare. especially child } \\
\text { care }\end{array}$ & $\begin{array}{l}\text { Yes. to a point where (male) } \\
\text { children are placed elsewhere } \\
\text { or children are sold or } \\
\text { abandoned }\end{array}$ \\
\hline $\begin{array}{l}\text { Female income-earning is } \\
\text { possible }\end{array}$ & $\begin{array}{l}\text { Moneylending: food pro- } \\
\text { cessing and trading: petty } \\
\text { manufacturing; wage } \\
\text { labour less common }\end{array}$ & $\begin{array}{l}\text { Food processing and } \\
\text { trading: wage labour } \\
\text { common/frequent but not } \\
\text { always avaitable }\end{array}$ & $\begin{array}{l}\text { via loans. mortgages. sale } \\
\text { of assets }\end{array}$ & $\begin{array}{l}\text { via begging. prostitution and } \\
\text { FFW }\end{array}$ \\
\hline $\begin{array}{l}\text { Female production is } \\
\text { possible }\end{array}$ & $\begin{array}{l}\text { Fields: gardens: ponds: } \\
\text { poultry: small stock: trees: } \\
\text { cows }\end{array}$ & $\begin{array}{l}\text { Trees: small stock: cows: } \\
\text { CPR: gleaning }\end{array}$ & $\begin{array}{l}\text { Garden species may be } \\
\text { less drought-prone. etc. } \\
\text { Gathering of famine foods }\end{array}$ & $\begin{array}{l}\text { Greater pressure on CPR. } \\
\text { Gathering of famine foods }\end{array}$ \\
\hline $\begin{array}{l}\text { Female social organisation } \\
\text { gives returns }\end{array}$ & $\begin{array}{l}\text { FHH Networks: positive. } \\
\text { Semi-formal/formal } \\
\text { groups: positive }\end{array}$ & Labour gangs: positive & $\begin{array}{l}\text { FHH networks: children } \\
\text { of both sexes can be } \\
\text { protected }\end{array}$ & Brothel-keeping \\
\hline $\begin{array}{l}\text { Female assets can be } \\
\text { disposed of (jewellery. } \\
\text { pots) }\end{array}$ & Last resort & Common. frequent & More, higher value & Few. low value \\
\hline $\begin{array}{l}\text { Provision of company or } \\
\text { sexual favours in return } \\
\text { for gifts is socially } \\
\text { sanctioned }\end{array}$ & FHH only & $\begin{array}{l}\text { Accepted as sometimes } \\
\text { necessary }\end{array}$ & $\begin{array}{l}\text { Protection by male kin. } \\
\text { Remarriage (if still young) } \\
\text { Prostitution. FHH } \\
\text { Networks may exploit to } \\
\text { survive }\end{array}$ & Prostitution \\
\hline
\end{tabular}




\section{References}

Bantje, H., 1982a, 'Household characteristics and nut ritional status in the Rufiji Valley', Research Paper No 72, BRALUP, University of Dar es Salaam, April

-1982b, 'Food flows and dietary patterns in lkwiriri Village', Research Paper No 74, BRALUP, University of Dar es Salaam, February

Begum, S., 1985, 'Women and technology: rice processing in Bangladesh', in IRR1, Women in Rice Farming, Gower, Aldershot, pp 221-242

Brierley, J.S., 1976, 'Kitchen gardens in the West Indies with a contemporary study from Grenada', The Journal of Tropical Geography, 43, 30-40

Callear, D., 1982, The social and cultural factors involved in production by small farmers in Wedza Communal Area, Zimbabwe, of maize and its marketing', Repor $R R D 17$, UNESCO, Paris

Deere, C. D. and M. Leon de Leal, 1982, "Women in Andean Agriculture', Women, Work and Developmen 4 , ILO, Geneva

Eijnatten, C. L. M. van, 1971, 'Home gardens: principles and experiences', paper to Seminar on Agricultural Research in West Africa, University of lbadan

Ensminger, J., 1985, 'The commercialisation of pastoralists: effects of seasonality, age, gender and wealth upon time allocation', paper to IFPRI/FAO/AID Workshop on Seasonal Causes of Household Food Insecurity, Policy Implications and Research Needs, Annapolis, Maryland, December 10-13

ESCAP/FAO, 1979, 'Women's transplanting, organisations, Mukulamada, Matale District, Sri Lanka', in Transfer of Knouledge and Skills Among Peer Groups: A Manual on Meihodology, Inter-country Project for the Promotion and Training of Rural Women in Income-raising Group Activities, Bangkok

Evenson, R. E., 1985, 'Observations on institutions, infrastructure technology and women in rice farming', in IRRI, Women in Rice Falming, Gower, Aldershot, pp 21-36

Evers, H. D., 1981: 'The contribution of urban subsistence production to incomes in Jakarta', Bullerin of Indonesian Sullies, vol 16 no 2, pp 89-96

Foley, G., P. Moss and L. Timberlake, 1984, Sioves and Trees, IIED, London and Washington

Greenough, P. R., (n.d.) 'Some notes on peasant prostitutes recruited in times of famine', WID Notes, MUCIA Women in Development Network, Land Tenure Centre, University of Wisconsin, 4-7

- 1982, Prosperin and Misery in Modern Bengal: The Fanine of 1943-44, Oxford University Press
Huss-Ashmore, R., 1982, 'Seasonality in rural Highland Lesotho: method and policy', in J. Jiggins (ed.), A Repor' on the Regional Workshop on Seasonal Variaitions in the Provisioning. Nurition and Healih of Rural Families, AMREF, Nairobi, 31 March-2 April

Illo, J. F. 1., 1985, 'Wives at work: patterns of labour force participation in two rice-farming villages in the Philippines', in 1RR1, Women in Rice Farming, Gower, Aldershot, pp 71-90

Institute of Social Studies, 1979, Impaci on Women Workers. Maharashira Emploimenı Guaraniee Scheme. A Siudi, ILO, Geneva, December

Jahan, R., 1979, 'Situation of deviant women', in Women for Women: The Simation of Women in Bangladesh, BRAC Printers, Dhaka, pp 265-84

Jiggins, J., 1983, 'The quest for autonomy: women's participation in agricultural credit and banking, paper to Workshop for Policymakers on Women's Participation in Agricultural Credit and Banking for Selected Eastern and Southern African Countries, AFRACA/FAO, Nairobi, 14-17 March

- 1986, 'Problems of understanding and communication at the interface of knowledge systems', paper to Conference on Gender lssues in Farming Systems Research and Extension, University of Florida, February 26-March 1

Jones, C., 1982, 'Women's labour allocat ions and irrigated rice production in North Cameroon', paper to International Association of Agricultural Economics Meeting, August 30, Jakarta

Kebede, H., 1978, "Improving village water supplies in Ethiopia: a case study of socio-economic implications', UNECA/UNICEF, Addis Ababa

Kerven, C., 1979, Urban and Rural Female-Headed Households' Dependence on Agriculure, National Migration Study, Central Statistics Office, Ministry of Finance and Development Planning/Rural Sociology Unit, Ministry of Agriculture, Gaberone

Khan, Z. Rahman, 1979, 'Women in rural development programme - a study of Birangaon village', in Women for Women: Siluaiion of Women in Bangladesh, BRAC Printers, Dhaka, pp 439-54

Kurian, R., 1981, 'The position of women workers in the plantation sector of Sri Lanka', HO Working Paper, WEP 10/WP 18, 1LO, Geneva

Muzale, P. J. and D. K. Leonard, 1985, 'Kenya's experience with women's groups in agricultural extension: strategies for accelerating improvements in food production and nutrition awareness in Africa, Agriculiural Administraion, vol 19 no 1 , pp 13-28

Nath, J., 1979, 'The role of women in rural Bangladesh - a study of Nantupurvillage', in Women for Women: Siluarion of Women in Bangladesh, BRAC Printers, Dhaka, pp 425-38 
Ninez, V. K., 1984, 'Household gardens in Peru: ecological, nutritional and economic, perspectives on indigenous small-scale food production', CIP, Lima

Obbo, C., 1980, African Women: Their Struggle for Economic Independence, Zed Press, London

Otaala, B., 1980, Davcare in Eastern Africa. a survey of Botswana, Kenya, Seychelles. Tanzania, ECA/ATRCW, November

Phongpaichit, P., 1980, 'Rural women of Thailand: from peasant girls to Bangkok masseuses', ILO Working Papers, WEP10/WP 14, 1LO, Geneva

Rahaman, M. M., 1981, 'The causes and effects of famine in the rural population: a report from Bangladesh', in J. R. K. Robson (ed.), Famine, Gordon and Breach Science Publishers, pp 135-8

Risseeuw, C., 1980, The Wrong End of the Rope, Research Project Women and Development, University of Leiden

Ryan, J. G. and R. D. Ghodake, 1980, "Labor market behaviour in rural villages of South India: effects of season, sex and socioeconomic status', Progress Report Economics Program 15, ICRISAT, Andhra Pradesh, August

Saul, M., 1981, 'Beer, sorghum and women: production for the market in Upper Volta', Africa, vol 51 no 3
Schofield, S., 1974, 'Seasonal factors affecting nutrition in different age groups and especially preschool children', Jounal of Development Sudies, vol 11 no 1, October, pp 22-40

Scott, G., 1984, 'Women and human settlement', CUSO Journal, Women in Development, pp 49-52

Stoler, A., 1978, 'Garden use and household economy and future development', Culture and Agriculture, Bulletin of the Agricultural Study Group on Agrarian Systems, 5, pp $1-8$

Vidyarthi, V., 1984, 'Energy and the poor in an Indian village', World Development, vol 12 no 8 , pp $821-36$

Watson, G. A., 1985, 'Women's role in the improvement of rice farming systems in coastal swamplands', in IRRI, Women in Rice Farming, Gower, Aldershot, pp 187-208

White, B., 1985, 'Women and the modernisation of rice agriculture; some general issues and a Javanese case study', in IRRI, Women in Rice Farming, Gower, Aldershot, pp 119-148

Wily, L., 1981, 'Women and Development: a case study of ten Tanzanian villages, Arusha', a report prepared for the Arusha Planning and Village development Project, Arusha, Tanzania, March

World Food Programme, 1979, 'Bangladesh: National relief works programme for land and water development', WFP/CFA 8/8 Add 5, Rome 